\title{
A FORGOTTEN BUT IMPORTANT RISK FACTOR FOR SEVERE HYPONATREMIA: MYXEDEMA COMA
}

doi: 10.1590/S1807-59322010000400015

Ayse Kargili, ${ }^{\mathrm{I}}$ Faruk Hilmi Turgut, ${ }^{\mathrm{II}}$ Feridun Karakurt, ${ }^{\mathrm{I}}$ Benan Kasapoglu, ${ }^{\mathrm{III}}$ Mehmet Kanbay, ${ }^{\mathrm{II}}$ Ali Akcay ${ }^{\mathrm{II}}$

\section{INTRODUCTION}

Hypothyroidism is one of the most prevalent endocrine diseases. It can lead to a variety of clinical situations, including congestive heart failure, ileus, hypothermia, electrolyte disturbances and coma. ${ }^{1}$ Hyponatremia, on the other hand, is the most common electrolyte abnormality encountered in clinical practice. ${ }^{2}$ Herein, we report a case of myxedema coma with severe hyponatremia.

\section{CASE HISTORY}

A 78-year-old male was admitted to the emergency department for confusion. He had had a cerebrovascular event five years ago and had been using anti-hypertensive medication since then. His medications included acetylsalicylic acid $300 \mathrm{mg} /$ day and lacidipine $4 \mathrm{mg} /$ day. On physical examination, the patient was comatose and had a blood pressure of $90 / 60 \mathrm{mmHg}$, heart rate of 52 beats $/ \mathrm{min}$, respiratory rate of 18 breaths/min and temperature of 35.5 ${ }^{\circ} \mathrm{C}$. Systemic examination revealed coarse skin, hypoactive bowel sounds, decreased breath sounds and nonpitting pretibial edema. His laboratory findings were as follows: hemoglobin $11.6 \mathrm{~g} / \mathrm{dL}$, WBC 7400/mL, glucose $94 \mathrm{mg} /$ $\mathrm{dL}$, urea $30 \mathrm{mg} / \mathrm{dL}$, creatinine $0.5 \mathrm{mg} / \mathrm{dL}$, calcium $8.4 \mathrm{mg} /$ $\mathrm{dL}$, sodium $106 \mathrm{mmol} / \mathrm{L}$, potassium $4.27 \mathrm{mmol} / \mathrm{L}$, CRP $13.6 \mathrm{mg} / \mathrm{L}$, TSH $61.24 \mathrm{uIU} / \mathrm{mL}$, and T4 $<0.3 \mathrm{pmol} / \mathrm{L}$. After

\footnotetext{
IDepartment of Endocrinology, Faculty of Medical School, Fatih University - Ankara, Turkey.

II Department of Nephrology, Faculty of Medical School, Fatih University - Ankara, Turkey.

III Department of Internal Medicine, Faculty of Medical School, Fatih University - Ankara, Turkey.

Tel.: + 90-0312-4829166 or 2126262

Email: benankasapoglu@ hotmail.com
}

the patient was diagnosed with severe hyponatremia, his medications were reevaluated; however, no anti-depressants, diuretics or other medications that can cause hyponatremia were reported. The patient's urine osmolarity was 280 $\mathrm{mOsm} / \mathrm{kg}$, and the urine sodium level was $96.02 \mathrm{mmol} / \mathrm{L}$. A random cortisol level was detected as $17.6 \mathrm{ug} / \mathrm{dL}$ (reference range: $5-25 \mathrm{ug} / \mathrm{dL}$ ). Arterial blood gas testing revealed a hypercarbia with $\mathrm{pCO}_{2}$ of $66.2 \mathrm{mmHg}$ and $\mathrm{pH}$ of 7.33. No signs of an acute cerebrovascular event or cerebral edema were detected in brain computed tomography. Myxedema coma was diagnosed, and L-thyroxine sodium $500 \mu \mathrm{g}$ was administered once orally and continued at a dose of 100 $\mu \mathrm{g} / \mathrm{day}$ by nasogastric tube. Isotonic saline was started at a rate of $100 \mathrm{~mL} / \mathrm{h}$. Hyponatremia recovered gradually with isotonic saline infusion and L-thyroxine therapy. On the fifth day of her hospitalization, the control serum sodium level was $134 \mathrm{mmol} / \mathrm{L}$; the patient's mental state was markedly improved, and the patient was discharged.

\section{DISCUSSION}

Myxedema coma is an uncommon but potentially lethal condition. ${ }^{2}$ It usually occurs in older patients with long-standing hypothyroidism. Classic manifestations of hypothyroidism include extreme bradycardia, hypotension and delayed relaxation of deep tendon reflexes. ${ }^{3}$ Myxedema coma was diagnosed in this case based on clinical and laboratory signs including altered mental status, decreased body temperature, very high TSH and low free T4.

Hyponatremia is frequently observed in hospitalized patients. It needs to be treated effectively, and the rate of correction should be adapted to the clinical situation. In our case, the serum sodium level increased gradually with L-thyroxine therapy and isotonic saline infusion. We believe that the coma was associated with both hyponatremia and 
hypothyroidism in this patient. Although hypothyroidism is known to be a cause of hyponatremia, Kilpatrick et al. failed to identify a definite association between hypothyroidism and hyponatremia. ${ }^{4,5}$ Moreover, a case of life-threatening hyponatremia due to cessation of L-thyroxine treatment has been reported elsewhere. ${ }^{6}$ Because there was no etiological factor for hyponatremia apart from hypothyroidism in this case, we consider that the hypothyroidism caused this manifestation of hyponatremia.

The correct management of hyponatremia is extremely critical, not only in preventing complications but also in avoiding harm to the patient. A 4 - to $6-\mathrm{mmol} / \mathrm{L}$ increase in serum sodium concentration corrects many neurological symptoms in the most seriously ill patients. Nevertheless, overcorrection of hyponatremia increases the risks of iatrogenic brain damage. In a recent review, the suggested therapeutic goals for correction rates are $6-8 \mathrm{mmol} / \mathrm{L}$ in 24 hours, $12-14 \mathrm{mmol} / \mathrm{L}$ in 48 hours, and $14-16 \mathrm{mmol} / \mathrm{L}$ in 72 hours. $^{7}$

In conclusion, severe hyponatremia can be a lifethreatening problem in clinical contexts and should be carefully managed. In light of this case, physicians should include hypothyroidism in the differential diagnosis of every patient with hyponatremia.

\section{REFERENCES}

1. Roberts CG, Ladenson PW. Hypothyroidism. Lancet. 2004;363:793-803.

2. Anderson RJ, Chung H-M, Kluge R, Schrier RW. Hyponatremia: a prospective analysis of its epidemiology and the pathogenetic role of vasopressin. Ann Intern Med. 1985;102:164-8.

3. Wall CR. Myxedema coma: diagnosis and treatment. Am Fam Physician. 2000; 62:2485-90.

4. Reynolds RM, Seckl JR. Hyponatraemia for the clinical endocrinologist. Clin Endocrinol (Oxf). 2005;63:366-74.
5. Kilpatrick ES. Disorders of sodium balance: hypothyroidism and hyponatraemia: an old wives' tale? BMJ. 2006;332:854.

6. Sari R, Sevinc A. Life-threatening hyponatremia due to cessation of Lthyroxine. J Natl Med Assoc. 2003;95:991-4.

7. Sterns RH, Nigwekar SU, Hix JK. The treatment of hyponatremia. Semin Nephrol. 2009;29:282-99. 